\title{
SKIN MANIFESTATIONS IN END STAGE RENAL DISEASE PATIENTS ON HEMODIALYSIS.
}

1. FCPS (Internal Medicine) Assistant Professor Medicine Chandka Medical College, Larkana.

2. FCPS (Internal Medicine), FRCP

(London)

Professor Medicine

Chandka Medical College, Larkana.

3. FCPS (Internal Medicine)

Consultant Physician

Chandka Medical College Hospital Larkana.

4. FCPS (Dermatology) Associate Professor Chandka Medical College, Larkana

5. FCPS (Internal Medicine), FRCP (Glasgow)

Professor Medicine

Chandka Medical College, Larkana.

6. MCPS, FCPS (Internal Medicine)

Assistant Professor Medicine

Chandka Medical College, Larkana.

Correspondence Address:

Dr. Zahid Ali Shaikh

Department of Medicine

Chandka Medical College, Larkana

drzahidali1979@yahoo.com

Article received on:

07/03/2019

Accepted for publication:

15/06/2019

Received after proof reading:

$30 / 09 / 2019$
Zahid Ali Shaikh', Aftab Hussain Shah², Aneel Kumar ${ }^{3}$, Irfan Ahmed Shaikh", Bashir Ahmed Shaikh ${ }^{5}$, Kamlesh Kumar Ahuja ${ }^{6}$

ABSTRACT: Chronic kidney disease (CKD) is a world public health problem that is related with high morbidity and mortality. CKD patients can present with different skin manifestations, often benign with much impact on quality of patients life. Study Design: Case-series study. Setting: Nephrology Unit Civil Hospital Larkana. Period: From $1^{\text {st }}$ January 2018 to $30^{\text {th }}$ June 2018. Material and methods: 141 patients of ESRD on regular HD for at least 1 month. Patients were chosen randomly for evaluation of cutaneous changes regardless of their gender, age, sex and etiology of ESRD. General and dermatological examination of the skin, hair, nails, and oral mucosa was performed by consultant dermatologist. Data were analyzed by using IBM SPSS version 23.0. Descriptive analyses performed using mean with standard deviation and median with inter quartile ranges of quantitative data set. Count and percentages were reported for categorical data set. Results: In the present study there were one hundred and forty one patients. Out of them skin manifestations of patients, $87.9 \%$ had Xerosis, $31.9 \%$ found with skin hyper pigmentation, 9.2\% had Subungal Hyperkeratosis, 24.1\% had Uremic Pruirtis, 45.4\% had Pallor, and $6.4 \%$ found with Bruises. There were $9.9 \%$ cases of Alopecia, $17.7 \%$ cases of half $n$ half nail, $1.4 \%$ cases of half $n$ half nail with alopecia, $9.2 \%$ cases of Koilionychia, $0.7 \%$ cases of Koilionychia with alopecia, $2.8 \%$ found with koilonychias and half $\mathrm{n}$ half nail, $2.1 \%$ with leuconycia and koilionychia, 15.5\% with Leuconychia, 2.1\% found with Leuconychia and alopecia, and $0.7 \%$ found with Leuconychia, koilonychia \& alopecia in Hair and Nail changes. Conclusion: The range of skin manifestations vary in different studies. Although often benign with much impact on quality of patient's life and life can be threatening. Early treatment of skin disorders can improve the quality of life.

Key words: $\quad$ CKD (Chronic Kidney Disease), ESRD (End Stage Renal Disease), GFR (Glomerular Filtration Rate), HD (Hemodialysis).

Article Citation: Shaikh ZA, Shah AH, Kumar A, Shaikh IA, Shaikh BA, Ahuja KK. Skin manifestations in end stage renal disease patients on hemodialysis. Professional Med J 2019; 26(10):1678-1681.

DOI: 10.29309/TPMJ/2019.26.10.3390

\section{INTRODUCTION}

Chronic kidney disease (CKD) is a global public health issue that is associated with high morbidity and mortality. In Pakistan CKD prevalence is higher than expected have been reported by population-based health survey of 1023 people by Kazmi et al. ${ }^{1}$ CKD patients can presents with different skin manifestations. Chronic kidney disease has been classified into various stages. Stage 1, with Normal Glomerular Filtration Rate (GFR) but at risk of CKD. Stage 2, with a GFR of 60 to $90 \mathrm{ml} /$ minute. Stage $3 \mathrm{GFR}$ of 30 to $60 \mathrm{ml} /$ minute. Stage 4 GFR of 15 to $30 \mathrm{ml} /$ minute. Stage 5 is for ESRD patients with a GFR rate less than $15 \mathrm{ml} /$ minute. $^{2}$
Variety of cutaneous manifestation have been observed in patients of ESRD, from benign asymptomatic with much impact on patients quality of life and can be life-threatening.

An earlier study by Udaykumar et $\mathrm{al}^{3}$ reported all hemodialysis patients of renal failure having atleast one cutaneous finding. Common skins manifestations are xerosis, pallor, hyperpigmentation, pruritus and half-and-half nails.

Multiple factors are involved in the pathogenesis of the skin manifestations in patients of ESRD, the fact could be that the hemodialysis is not as fully 
effective as a normal kidney can and this will not replace its endocrine function, resulting build-up of uremic substances \& electrolyte imbalance. ${ }^{4}$

The aim of this research is to explore the frequency of skin manifestations and their early recognition and start the early treatment that can improve the patient's quality of life. This study has been conducted in Nephrology Unit Civil Hospital Larkana.

\section{Methodology}

This case-series study included 141 patients of ESRD on regular HD for atleast 1 month. After taking the approval of ethical committee, patients were chosen randomly for evaluation of cutaneous changes regardless of their gender, age, sex and etiology of ESRD.

They all were subjected to a full assessment of history, investigations including urea, creatinine and serum electrolytes was done. A general and dermatological examination of the skin, hair, nails, and oral mucosa was performed by consultant dermatologist.

\section{Statistical Analysis}

Data were inserted and analyzed using IBM SPSS version 23.0. Descriptive analyses performed using mean with standard deviation and median with inter quartile ranges of quantitative data set. Count and percentages were reported for categorical data set. Bar chart and pie chart also used to give graphical presentation of data.

\section{RESULTS}

Table-I reports the baseline characteristics of studied samples. In the present study there were one hundred and forty one patients. $23.4 \%$ having the age group between 36 - 45 years old, $29.8 \%$ were aged $40-60$ years old. The mean age of patients was 45.2 (S.D $= \pm 14.8$ ) years. $65.2 \%$ samples were male. $22.7 \%$ patients had duration of $\mathrm{HD}$ between 3 - 6 months, $24.1 \%$ patients found with 13-34 month of duration, the median duration of $H D$ was $12(I Q R= \pm 20)$ months. $29.1 \%$ patients had diabetes, $23.4 \%$ had hypertension, $3.5 \%$ had renal stones, 3.5\% were APH, 21.3\% had Nephrolithasis, $4.3 \%$ had Idiopathic, $5 \%$ had
Eclampsia and $5.7 \%$ patients had Diabetes \& Hypertension as cause of ESRD. (Table-I)

Table-Il reports the median and IQR of biochemistry of patients. The Median of $\mathrm{Na}^{+}$was $135(\mathrm{IQR}= \pm 8)$, median of $\mathrm{K}^{+}$was $5.50(\mathrm{IQR}=$ $\pm 1.30)$, median of Urea was $85(I Q R= \pm 48)$ and median of Creatinine was $5(\mathrm{IQR}= \pm 1)$.

Table-III reports skin manifestations of patients. $87.9 \%$ had Xerosis, $31.9 \%$ found with skin hyperpigmentation, $9.2 \%$ had Subungal Hyperkertosis, $24.1 \%$ had Uremic Pruirtis, $45.4 \%$ had Pallor, and $6.4 \%$ found with Bruises.

There were $9.9 \%$ cases of Alopecia, $17.7 \%$ cases of half $n$ half nail, $1.4 \%$ cases of half $n$ half nail with alopecia, $9.2 \%$ cases of Koilonychia, $0.7 \%$ cases of Koilonychia with alopecia, $2.8 \%$ found with koilonychias and half $\mathrm{n}$ half nail, $2.1 \%$ with leuconycia and koilionychia, 15.5\% with Leuconychia, $2.1 \%$ found with Leuconychia and alopecia, and $0.7 \%$ found with Leuconychia, koilonychia \& alopecia in Hair and Nail changes.

\begin{tabular}{|c|c|c|c|}
\hline \multicolumn{2}{|c|}{ Characteristics } & $\mathbf{n}$ & $\%$ \\
\hline \multirow{6}{*}{ Age Group } & 12 - 25 years & 18 & 12.8 \\
\hline & 26 - 35 years & 30 & 21.3 \\
\hline & $36-45$ years & 33 & 23.4 \\
\hline & 46 - 60 years & 42 & 29.8 \\
\hline & $>60$ years & 18 & 12.8 \\
\hline & Mean ( \pm S.D) & $45.2( \pm 14.8)$ & \\
\hline \multirow{2}{*}{ Gender } & Male & 92 & 65.2 \\
\hline & Female & 49 & 34.8 \\
\hline \multirow{6}{*}{$\begin{array}{l}\text { Duration of } \\
\text { HD }\end{array}$} & $<=2$ months & 21 & 14.9 \\
\hline & $3-6$ months & 32 & 22.7 \\
\hline & $7-12$ months & 33 & 23.4 \\
\hline & $13-24$ months & 34 & 24.1 \\
\hline & $>24$ months & 21 & 14.9 \\
\hline & Median ( $\pm I Q R)$ & $12( \pm 20)$ & \\
\hline \multirow{9}{*}{$\begin{array}{l}\text { Cause of } \\
\text { ESRD }\end{array}$} & Diabetes & 41 & 29.1 \\
\hline & Hypertension & 33 & 23.4 \\
\hline & Renal Stones & 5 & 3.5 \\
\hline & $\mathrm{APH}$ & 5 & 3.5 \\
\hline & Nephrolithasis & 30 & 21.3 \\
\hline & Idiopathic & 6 & 4.3 \\
\hline & Eclampsia & 7 & 5.0 \\
\hline & $\begin{array}{l}\text { Diabetes \& } \\
\text { Hypertension }\end{array}$ & 8 & 5.7 \\
\hline & Others & 6 & 4.3 \\
\hline
\end{tabular}

Table-I. Baseline characteristics of studied samples $(n=141)$ 


\begin{tabular}{|l|c|c|}
\hline Parameters & Median & IQR \\
\hline $\mathrm{Na}+$ & 135 & 8 \\
\hline $\mathrm{K}+$ & 5.50 & 1.30 \\
\hline Urea & 85 & 48 \\
\hline Creatinine & 5 & 1 \\
\hline \multicolumn{2}{|c|}{ Table-II. Electrolytes analysis of studied samples } \\
& $(\mathbf{n = 1 4 1 )}$
\end{tabular}

\begin{tabular}{|l|c|c|}
\hline \multicolumn{1}{|c|}{ Disease } & n & $\%$ \\
\hline Xerosis & 124 & 87.9 \\
\hline Skin color (hyperpigmentation) & 45 & 31.9 \\
\hline Subungal Hyperkertosis & 13 & 9.2 \\
\hline Uremic Pruiritis & 34 & 24.1 \\
\hline Pallor & 64 & 45.4 \\
\hline Bruises & 9 & 6.4 \\
\hline Alopecia & 14 & 9.9 \\
\hline Half n Half nail & 25 & 17.7 \\
\hline half n half nail, alopecia & 2 & 1.4 \\
\hline Koilionychia & 22 & 15.5 \\
\hline Koilonychia, alopecia & 1 & 0.7 \\
\hline Koilonychia, half $n$ half nail & 4 & 2.8 \\
\hline Leuconychia \& Koilionychia & 3 & 2.1 \\
\hline Leuconychia & 22 & 15.5 \\
\hline leuconychia, alopecia & 3 & 2.1 \\
\hline Leuco, Koilo, alopecia & 1 & 0.7 \\
\hline
\end{tabular}

Table-III. Frequency of skin manifestations among studied patients $(n=141)$

Frequency of Disease among Studied Patients $(n=141)$

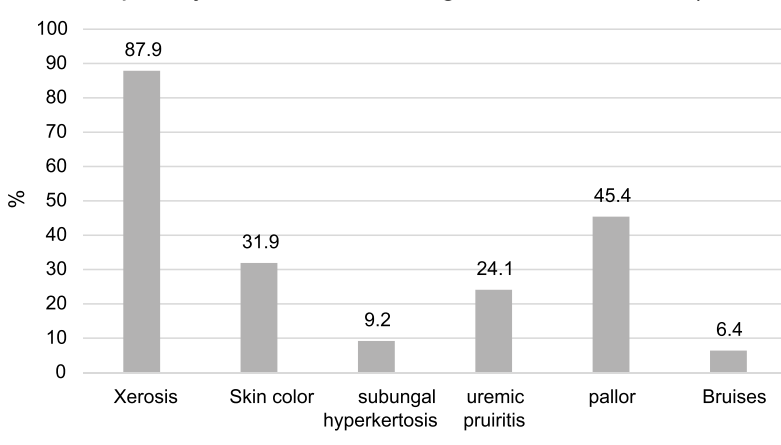

Bar Chart-1

\section{DISCUSSION}

ESRD refer to irreversible loss of endogenous renal function and skin alterations in the ESRD patients on hemodialysis are frequently found. Xerosis is most common finding observed in our study $(87.9 \%)$ and that causing increases the susceptibility to infections. Reported incidence ranged from $46-90 \% .^{3-5}$

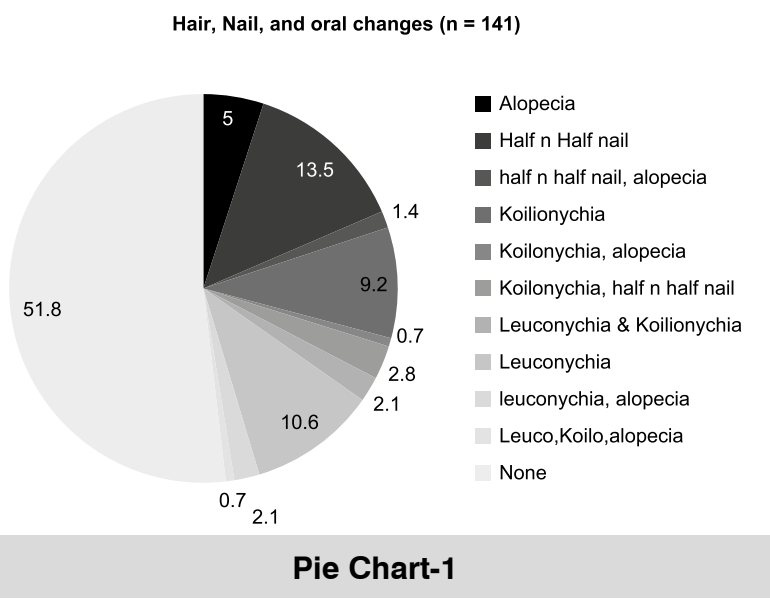

Skin Pallor because of anemia was seen in $45.4 \%$ of patients. This was low incidence with the findings of Girisha et al were reported it in $65 \%$ of patients. ${ }^{6}$

The anemia is due to anorexia and low level of erythropoietin secretion by the kidney. ${ }^{7}$

Skin hyperpigmentation is also common manifestation in patients with ESRD. In our study $31.9 \%$ of cases had hyperpigmentation. Similar incidence $32.3 \%$ was observed by Tawade and Gokhale. ${ }^{8}$ This occurs due to the accumulation of Melanocyte Stimulating Hormone as kidneys cannot excrete it.

Uremic pruritus is one of the most disturbing cutaneous problems seen in patients of ESRD. It was observed in $24.1 \%$ of cases. Quality of sleep and daily activities in most of our patient is affected due to this disorder. In a study done by Tawade and Gokhale ${ }^{8}$ they have reported 34\% cases, but in local study done by Muhammad anees et al reported $69 \%$ cases. ${ }^{9}$ Studies show a reduced the incidence of pruritus is may be due to better technique of dialysis.

Among nail changes, half and half nails (17.5\%) were the most commonly seen nail findings in ESRD. This was comparable to the results of other study abderrahmen et al is $13.5 \%$ of patients. ${ }^{10}$ Koilonychias reported 15.5 in our study. Subungal Hyperkeratosis were reported $9.2 \%$ comparing to our local study by Muhammad anees et al reported $23.5 .5 \% .^{9}$ Leuchonychia reported $15.5 \%$, 
same incidence with the findings of Girisha et al who reported it in $15 \%$ of patients. ${ }^{6}$

Diffuse alopecia was reported $9.9 \%$ in this study and compare to Girisha et al who reported it $7 \%$ of patients. ${ }^{6}$

\section{CONCLUSION}

The range of skin manifestations vary in different studies. This study is a joint effort between dermatologists and nephrologists for early detection of skin disorders in ESRD patients. Although often benign with much impact on patient's quality of life and can be life-threatening. Early treatment of skin disorders can improve the quality of life. Prophylactic measures should be taken by patients to prevent skin disorders, such as emollients use for pruritus and xerosis, avoidance of sun and exposure sun screens for hyperpigmentation.

\section{Copyright $\odot 15$ June, 2019.}

\section{REFERENCES}

1. Kazmi WH, Shahid K, Yousuf A, Osmani $A H$, Marmoos TH, Warsi FA, \& Khan S. A higher than expected prevalence of chronic kidney disease in Pakistan. $J$ Am Soc Nephrol 2007; 18:540.

2. KDIGO clinical practice guideline for the evaluation and management of chronic kidney disease. Kidney Int. 2013 Jan; 3 (1) (Suppl): 1 - 1 50.).
3. Udayakumar P, Balasubramanian S, Ramalingam KS, Lakshmi C, Srinivas CR, Mathew AC. Cutaneous manifestations in patients with chronic renal failure (CRF) on hemodialysis. Indian J Dermatol Venereol Leprol. 2006; 72:119-25.

4. Goldman, L, Schafer Al: Chronic kidney disease. In: Goldman's Cecil Medicine, Expert Consult Premium Edition, 24th Ed., Philadelphia, Elsevier Saunders, 2012.

5. Bencini PL, Montagnino G, Citterio A, Graziani G, Crosti C, Ponticelli C. Cutaneous abnormalities in uremic patients. Nephron. 1985; 40:316-21.

6. Banavasi S Girisha, Tonita M Noronha, Ashok Menon, Akshata C Alva. Cutaneous manifestations in patients with end stage renal disease on hemodialysis. International Journal of Contemporary Medical Research 2016; 3 (5):1386-88.

7. Goddard J, Turner AN, Cumming AD, Stewart LH. Kidney and urinary tract diseases. Davidson's principles and practice of medicine. 20th edition. Churchill LivingstElsevier. 2006; 455-518.

8. Tawade N, Gokhale BB. Dermatologic manifestation of chronic renal failure. Indian J Dermatol Venereol Leprol. 1996; 62:155-6.

9. Muhammad anees et al Factors affecting dermatological manifestations in patients with end stage renal disease J Coll Physicians Surg Pak 2018 Feb; 28(2):98-102.

10. Abderrahmen et al Cutaneous abnormalities in patients with end stage renal failure on chronic hemodialysis J Dermatol Case Rep. 2014 Dec 31; 8(4): 86-94.

\begin{tabular}{|c|l|l|l|}
\hline \multicolumn{3}{|c|}{ AUTHORSHIP AND CONTRIBUTION DECLARATION } \\
\hline Sr. \# & \multicolumn{1}{|c|}{ Author-s Full Name } & Contribution to the paper & Author's Signature \\
\hline 1 & Zahid Ali Shaikh & 1st Author \\
\hline 2 & Aftab Hussain Shah & 2nd Author \\
\hline 4 & Aneel Kumar & 3rd Author & \\
\hline 5 & Bashir Ahmed Shaikh & 5th Author & \\
\hline 6 & Kamlesh Kumar Ahuja & 6th Author & \\
\hline
\end{tabular}

